\title{
Siklus 3M Meningkatkan Keprofesionalan Guru Dalam Pembelajaran Daring
}

\author{
Murniasih \\ SMP Negeri 1 Wanasari \\ murniasihmpd01@gmail.com
}

\section{Article History}

accepted 01/12/2020

approved 01/01/2021

published 01/03/2021

\begin{abstract}
The rapid spread of covid 19 caused many deaths prompting the government to issue a policy regarding the learning process carried out at home through online learning, namely a learning process that utilizes informatics and communication technology (ICT) with its own characteristics learning interactions across time and space that can lead to various types of learning interactions. In online learning processes, teacher professionalism is needed, especially in utilizing the internet and communication media, namely cellphones, for that we need an approach through the $3 \mathrm{M}$ cycle, which is a supervision method for monitoring and evaluating the online learning process by communicating, monitoring and describing what is done continuously. The result of this $3 \mathrm{M}$ cycle is the increased skills of teachers in updating the internet, increased ability to operate communication media (cellphones and laptops) and the use of application applications used in online learning, communication becomes more effective and orderly administration. Through the $3 \mathrm{M}$ cycle, it turns out to be able to improve teacher professionalism in online learning, this can be seen in the ability to master the teaching material and develop it creatively, the use of informatics and communication technology and being able to reflect on its performance work even better.
\end{abstract}

Keywords: 3 M Cycle, Professionalism, and Online

\begin{abstract}
Abstrak
Penyebaran Corona Virus Disease (Covid-19) yang begitu cepat menyebabkan banyaknya kematian mendorong pemerintah mengeluarkan kebijakannya tentang proses belajar dilaksanakan dirumah melalui pembelajaran daring, yaitu proses pembelajaran yang memanfaatkan Teknologi Informatika dan Komunikasi (TIK) dengan ciri khas adanya interaksi pembelajaran lintas waktu dan ruang yang mampu memunculkan berbagai jenis interaksi pembelajaran. Pada proses pembelajaran daring diperlukan keprofesional guru khususnya dalam pemanfaatkan internet dan media komunikasi yaitu handphone, untuk itu diperlukan suatu pendekatan melalui siklus $3 \mathrm{M}$, yaitu metode supervisi untuk memonitoring dan mengevaluasi pada proses pembelajaran daring dengan cara mengkomunikasikan, memantau, dan mendeskripsikan yang dilakukan secara terus menerus. Hasil dari siklus $3 \mathrm{M}$ ini adalah meningkatnya keterampilan guru dalam mengupdate internet, meningkatnyai kemampuan mengoperasionalkan media komunikasi ( $\mathrm{Hp}$ dan Laptop) dan penggunaan aplikasi-aplikasi yang digunakan pada pembelajaran daring, komunikasi menjadi lebih efektif, serta tertib administrasi. Melalui siklus 3M ternyata mampu meningkatkan keprofesionalan guru pada pembelajaran daring, hal ini terlihat pada kemampuan dalam penguasaan materi ajar dan mengembangkannya secara kreatif, pemanfaatan teknologi informasi dan komunikasi, serta mampu melakukan refleksi kinerjanya untuk bekerja lebih baik lagi.
\end{abstract}

Kata kunci: Siklus 3M, Keprofesionalan, dan Daring

Social, Humanities, and Education Studies (SHEs): Conference Series https://jurnal.uns.ac.id/shes

p-ISSN 2620-9284 e-ISSN 2620-9292 


\section{PENDAHULUAN}

Corona Virus Disease (Covid-19) adalah salah satu jenis virus yang menyerang sistem saluran pernafasan. Penyakit karena infeksi virus ini disebut Covid-19 (Corona Virus Disease 2019) dan pertama kali ditemukan di kota Wuhan, China pada akhir Desember 2019. Virus ini menular dengan sangat cepat dan telah menyebar ke hampir semua negara, termasuk Indonesia, hanya dalam waktu beberapa bulan, tepatnya pada bulan Maret 2020. Di Kabupaten Brebes kasus pertama warganya positif Covid-19 yaitu dari klaster alumni peserta tablig akbar di Gowa Sulawesi Selatan. Sampai saat ini, sudah 812 kasus suspek Covid-19 di Kabupaten Brebes.

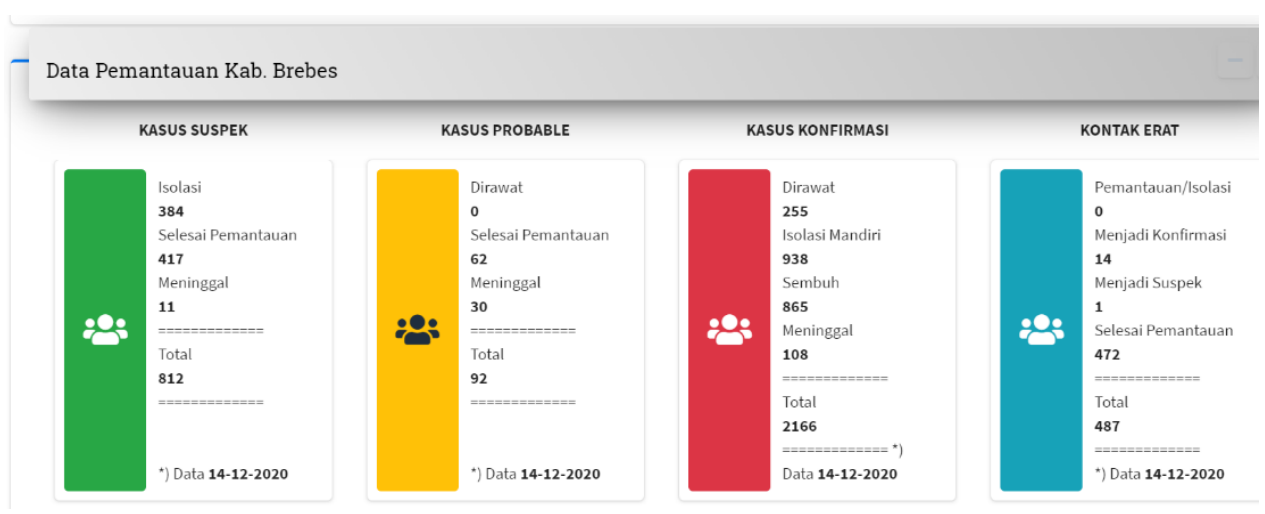

\section{Gambar 1. Data Tanggap Corona (Covid-19) Kabupaten Brebes}

Melihat penyebaran Covid-19 yang begitu cepat, maka Menteri Pendidikan dan Kebudayaan membuat surat edaran tentang Pelaksanaan Kebijakan Pendidikan dalam Masa Darurat Penyebaran Corona Virus Disease (Covid-19), disebutkan bahwa proses belajar dari rumah dilakukan melalui "pembelajaran daring/jarak jauh". Pembelajaran daring dilaksanakan dengan harapan memberikan pengalaman belajar yang bermakna bagi siswa, tanpa terbebani kompetensi dasar harus tuntas semua. Pembelajaran daring juga harus mempertimbangkan akses /fasilitas belajar. Produk aktifitas dari rumah harus diberi umpan balik yang bersifat kualitatif.

Pembelajaran daring adalah proses pembelajaran yang memanfaatkan Teknologi Informatika dan Komunikasi (TIK) dengan ciri khas adanya interaksi pembelajaran lintas waktu dan ruang yang mampu memunculkan berbagai jenis interaksi pembelajaran. Untuk melaksanakan proses pembelajaran daring maka perlu adanya persiapan baik dari guru sebagai pendidik, peserta didik maupun sarana dan prasarana. Hardianto menyatakan bahwa ada delapan kompetensi yang harus dimiliki guru dalam pembelajaran daring, yaitu: 1) menguasai dan update terhadap perkembangan internet, 2) lebih menguasai ilmu pengetahuan pokok dan pendamping, 3) kreatif dan inovatif dalam menyajikan materi, 4) mampu memotivasi siswa, 5) keterampilan dalam mendesain pembelajaran , 6) kemampuan mengelola pembelajaran 7) ketepatan dalam pemilihan bahan ajar, dan 8) kemampuan dalam mengontrol proses pembelajaran.

Beberapa prinsip yang harus diperhatikan dalam proses pembelajaran daring bahwa belajar itu adalah terbuka, sosial, personal, terbantukan, multipresentasi/ multiperspektif, dan bergerak. Belajar itu terbuka bertujuan agar peserta didik leluasa menentukan hal yang ingin dipelajarinya juga memberikan sebanyak mungkin kendali didalam strategi pembelajaran yang mengedepankan keluwesan waktu, tempat, dan aspek. Belajar itu sosial artinya belajar itu tempatnya berinteraksi baik dengan teman, guru, maupun teman didunia maya untuk membentuk kepribadiannya. Belajar itu personal, individu, ada kemandirian dan dengan belajar permasalahan akan terbantukan. Belajar itu 
multipresentasi/multiperspektif, artinya dengan pembelajaran daring bisa lebih leluasa mencari sumber belajar, dari sumber belajar yang beraneka ragam maka peserta didik mampu mempresentasikan dan memperspektifkan dari berbagai aspek, sehingga belajar terus bergerak menyesuaikan perkembangan terbaru untuk mencapai cita-citanya.

Ciri-ciri peserta didik aktif mengikuti proses pembelajaran daring menurut Dabbagh (dalam Hasanah, dkk., 2020:3) adalah: peserta didik asyik mencari tahu bukan diberi tahu, adanya kemampuan literasi terhadap pemakaian teknologi, mampu berkomunikasi secara interpersonal baik dengan guru maupun dengan teman sebayanya, mampu berkolaborasi dengan lingkungan sekitar atau dengan bermacam sistem yang mendukung pembelajaran daring, dan keterampilan untuk belajar mandiri.

Ada beberapa aplikasi yang digunakan oleh guru dalam pembelajaran daring, diantaranya adalah : google, quizizz, youtube, dan Computer Based Test (CBT) . Google didirikan oleh Larry Page dan Sergey Brin merupakan perusahaan yang mengumpulkan informasi dunia dan membuatnya dapat diakses dan bermanfaat oleh semua orang. Ada beberapa google yang digunakan dalam pembelajaran daring, diantaranya adalah Google form, google classroom, dan lainnya. Google form adalah layanan dari Google yang digunakan untuk membuat survey, tanya jawab, yang fungsi utamanya untuk membuat formulir baik untuk pengumpulan informasi maupun kuis secara online.Selain. Google form yang digunakan pada pembelajaran daring di SMP Negeri 1 Wanasari biasanya digunakan untuk memberikan tugas Latihan atau penilaian harian yang bentuknya essay secara online melalui website Google Classroom adalah bagian dari G Suite for Education yang hadir dalam versi aplikasi seluler yang penggunaannya semua anggota wajib mempunyai akun Google agar saling terhubung. Google classroom bermanfaat dalam pembelajaran daring, diantaranya adalah : proses setting mudah, cepat dan aman, hemat waktu, meningkatkan kerjasama dan komunikasi, penyimpanan data terpusat, efektivitas transaksi materi .

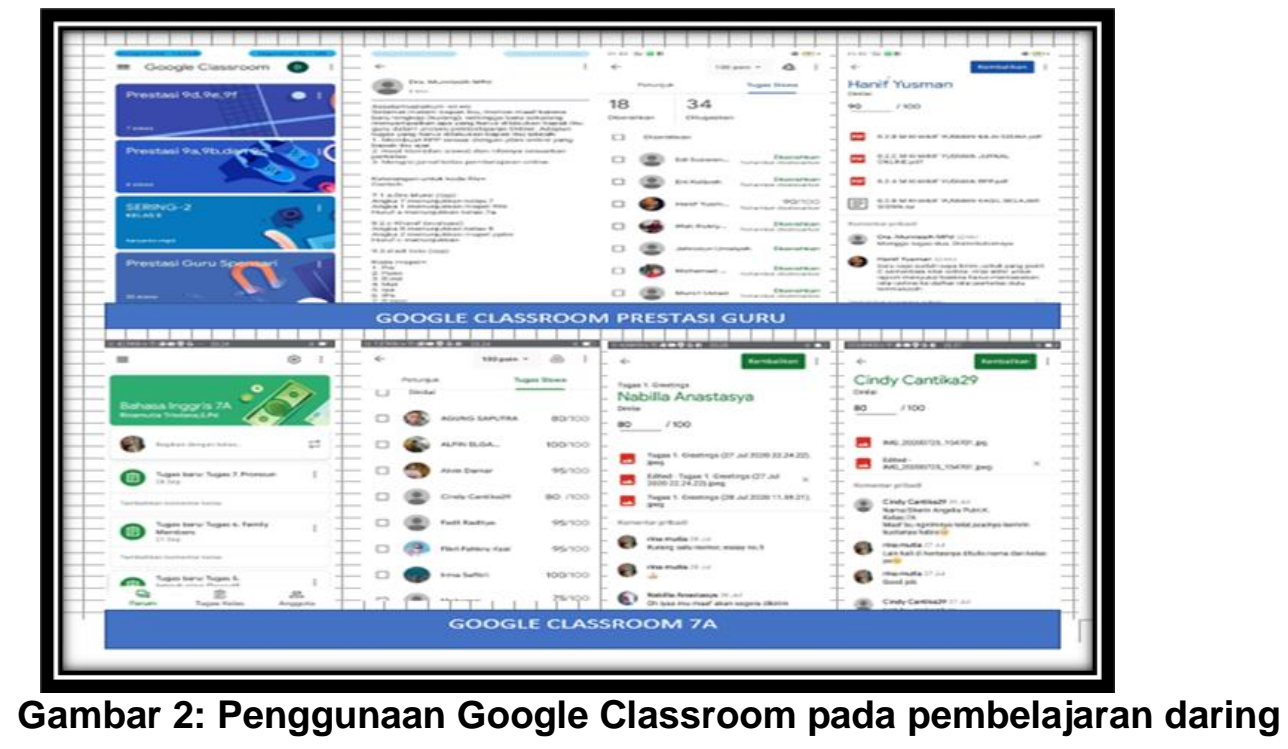

Quizizz yaitu web tool yang digunakan untuk membuat permainan kuis interaktif yang digunakan dalam pembelajaran dikelas (soal dalam bentuk pilihan ganda) dan ini digunakan untuk penilaian guru secara individu, sedangkan yang diselenggarakan secara bersama-sama waktunya serentak menggunakan CBT (Computer Based Test). Youtube adalah layanan file sharing berbasis web, video yang memungkinkan setiap orang mampuh untuk membangun profil publik atau semi-publik dalam sistem yang dibatasi, mengetahui dengan siapa akan disambungkan atau berbagi, juga dapat 
digunakan untuk melihat daftar koneksi yang dibuat orang lain. Youtube adalah meatode yang sangat efektif dalam pembelajaran daring, karena mampu menjelaskan hal-hal lebih baik daripada teks atau guru, juga hemat waktu dan biaya. Dengan melihat youtube, peserta didik tidak perlu melakukan praktek, bisa melihat langsung. Manfaat youtube dalam pembelajaran daring adalah : memberikan banyak informasi, sebagai video sarana pembelajaran, shering dengan lainnya, melatih kreatifitas, dan mampu menginsprirasi peserta didik untuk melakukan yang sama atau untuk melakukan inovatif, mendukung gaya belajar modern.

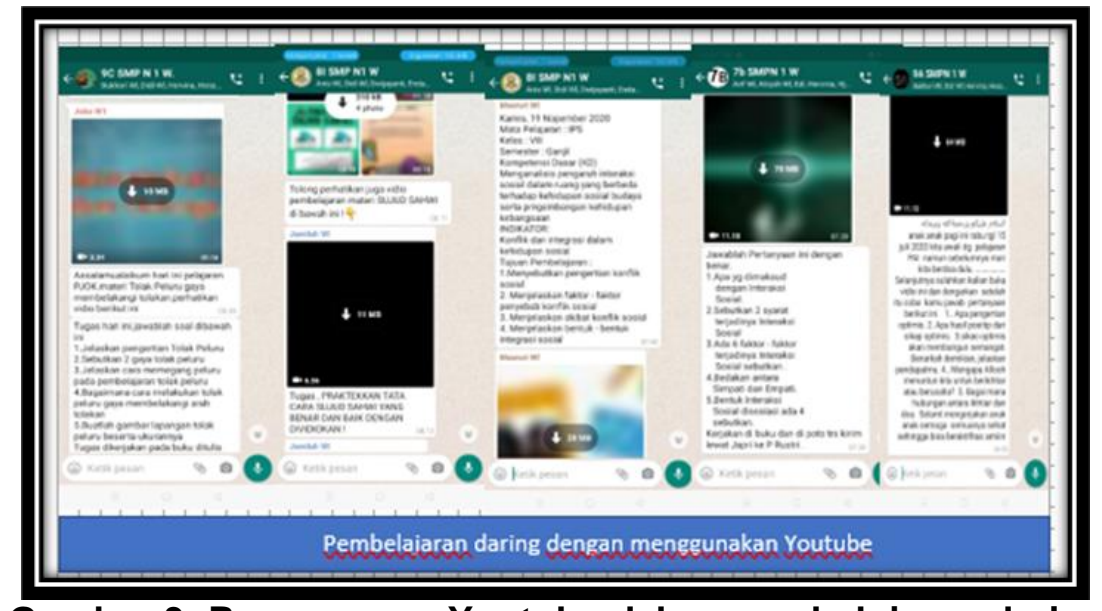

Gambar 3: Penggunaan Youtube dalam pembelajaran daring

Computer Based Test (CBT) adalah penggunaan computer dalam tes dan penilaian hasil belajar peserta didik, biasanya digunakan untuk tes yang berbentuk pilihan ganda dalam tes individu. Manfaat menggunakan CBT adalah menyesuaikan diri dengan perkembangan teknologi, menghemat anggaran, menghemat waktu dan tenaga guru dalam proses persiapan tes dan sesudah tes (selesai tes nilai langsung muncul), memudahkan peserta didik dalam mengerjakan ujian, dan hasil ujian lebih cepat, langsung dapat dianalisis oleh guru dan akurat hasilnya. Bodman dan Robinson menyatakan bahwa ada beberapa keunggulan kalau kita menggunakan CBT, yaitu mampu mengukur berbagai hal yang kompleks terkait dengan pengaetahuan dan kemampuan bernalar, dan untuk menilai dan menginterpretasi berbagai aspek dari performasi peserta didik dalam range yang lebar dari pemberian tugas yang mengukur kemampuan kognitif dan membandingkan hasilnya melalui profil yang telah diinterpretasikan.

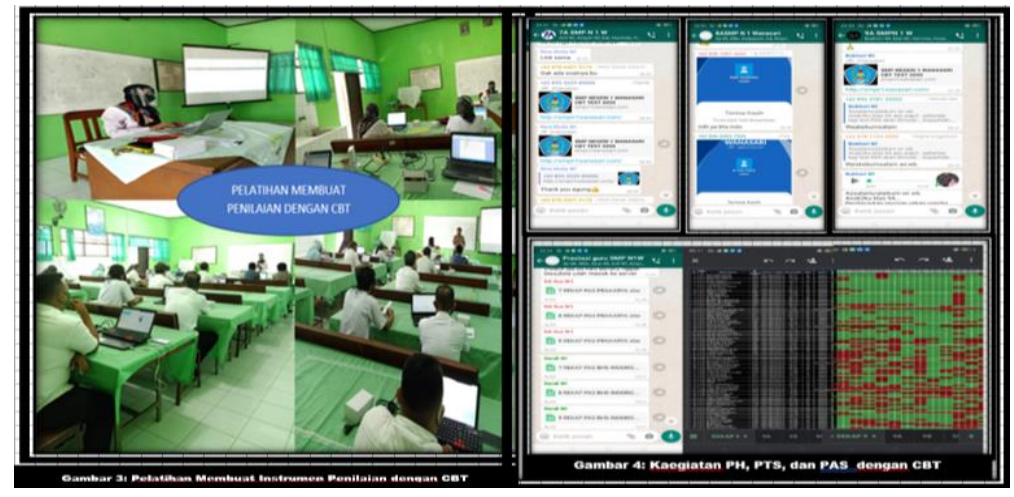

Gambar 4: Pelatihan CBT dan Pelaksanaan CBT 
HASIL DAN PEMBAHASAN

Siklus 3M (Mengkomunikasikan, Memantau, dan Mendeskripsikan) dan Keprofesionalan Guru

A. Siklus 3M (Mengkomunikasikan, Memantau, dan Mendeskripsikan)

Siklus 3M (Mengkomunikasikan, Memantau, dan Mendeskripsikan) adalah salah satu metode supervisi untuk memonitoring dan mengevaluasi pada proses pembelajaran daring dengan cara mengkomunikasikan, memantau, dan mendeskripsikan yang dilakukan secara terus menerus dengan tujuan terwujudnya pembelajaran daring yang bermakna sesuai dengan karakter peserta didik.

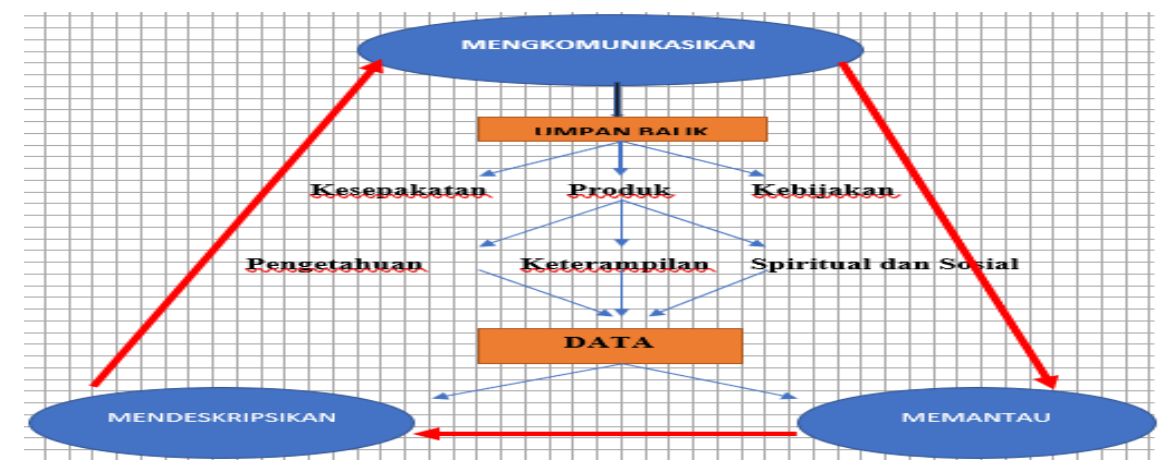

\section{Gambar 5. Siklus 3M (Mengkomunikasikan, Memantau, Mendeskripsikan)}

Komunikasi secara etimologi berasal dari Bahasa Latin "communis" yang berarti sama, "communico, communication, atau communicare" yang berarti membuat sama. Komunikasi adalah proses menciptakan suatu kesamaan atau suatu kesatuan pemikiran antara pemberi pesan (komunikator) dan penerima pesan (komunikan). Menurut Mulyana (2007:46) bahwa komunikasi merupakan proses penyampaian pikiran, makna, atau pesan dengan maksud untuk mencapai kesatuan dan kesamaan pemahaman. Proses komunikasi mempunyai dua tahap, yaitu proses komunikasi primer dan proses komunikasi sekunder.

Proses komunikasi primer adalah proses komunikasi yang menggunakan lambang yang secara langsung mampu menerjemahkan pikiran atau perasaan komunikator kepada komunikan. Lambang yang digunakan dalam komunikasi bisa bahasa verbal maupun non verbal. Bentuk komunikasi yang dilakukan dalam siklus 3M bermacam-macam, ada yang secara interpersonal misalnya untuk bimbingan atau pesan yang ditujukan secara interen, ada komunikasi kelompok baik kelompok kecil (MGMP Sekolah) maupun kelompok besar misalnya pelatihan, whorkshop, atau rapat koordinasi yang harus diikuti oleh semua guru. Proses komunikasi sekunder adalah proses komunikasi yang menggunakan alat atau sarana sebagai media setelah memakai lambang pada proses komunikasi primer misalnya telepon, surat kabar, radio, majalah, televisi, dan banyak lainnya. Sarana media yang sering digunakan adalah media online yaitu $\mathrm{Hp}$.

Dari proses komunikasi terjadilah pentransferan pesan/lambang yang akan direspon yang disebut umpan balik. Ardianto (2004) mengatakan umpan balik adalah reaksi yang timbul dari komunikan untuk memberikan pendapatnya terkait sesuatu (bisa berupa produk, atau hal lain) kepada komunikator dan bisa berlaku sebaliknya. Umpan balik menurut Kamus Besar Bahasa Indonesia (KBBI) adalah bahan yang diperoleh kembali dari penerapan sesuatu untuk unsur perbaikan dalam tindak lanjut. Umpan balik dapat berfungsi untuk mengetahui apakah pesan yang disampaikan oleh komunikator telah efektif untuk mencapai sasarannya. Umpan balik juga berfungsi sebagai motivasi, pemberitahuan/informasi, dan penguatan atas kejadian atau aktivitas yang telah dilaksanakan sehingga aktivitas tersebut tetap dipertahankan atau memberikan respons yang serupa dan pada aktivitas berikutnya dapat meningkat lagi. Umpan balik yang terjadi pada siklus 3M menghasilkan 
kebijakan, kesepakatan, dan produk. Produk dari umpan balik ada tiga macam, yaitu produk pengetahuan, keterampilan dan sikap yang selanjutnya akan dilakukan pemantauan apakah pruduk itu sesuai apa yang akan menjadi tujuan awal, bagaimana kuantitas dan kualitasnya, apakah perlu dipertahankan bahkan ditingkatkan atau perlu diperbaiki.

Memantau dalam Kamus Besar Bahasa Indonesia adalah mengatur atau mengontrol, mengecek, mengamati, dan memonitor. Kegiatan memantau dalam proses pembelajaran daring dilakukan dengan memantau WhatsApp Group Kelas, mengatur jadwal pembelajaran daring, mengecek apakah guru sudah melaksanakan pembelajaran daring atau belum sesuai dengan jadwal mengajarnya, mengamati apakah pembelajaran daring efektif tidak, bagaimana keaktifan komunikasi guru, dan memonitor apakah umpan balik berjalan dengan baik atau tidak yaitu dengan melihat seberapa banyak umpan balik yang diberikan oleh peserta didik, dan seberapa aktifkah guru memberikan umpan balik lagi . Hasil memantau yang berupa data kemudian dideskripsikan .

Mendeskripsikan pada siklus 3M adalah kebijakan, kesepakatan, atau hasil produk yang kemudian disebut sebagai data selanjutnya akan diolah yang kemudian akan digunakan untuk membuat kesimpulan apakah perlu diperbaiki , dipertahankan, atau ada penambahan, dan lainnya. Proses deskripsi ini juga digunakan untuk merefleksikan diri guru sebagai pendidik juga kepala sekolah sebagai pemimpin yang dilakukan terus menerus untuk mencapai mutu pembelajaran yang berkarakter sehingga terwujudlah pelajar yang berjiwa Pancasila yaitu beriman, bertaqwa kepada Tuhan Yang Maha Esa, beraklaq mulia, berkebinekaan global, kreatif, bernalar kritis, gotong royong, dan mandiri.

B. Keprofesionalan Guru

Salah satu kompetensi yang harus dimiliki seorang pendidik adalah kompetensi professional yaitu kemampuan seorang guru dalam mengelola proses belajar mengajar yang didukung oleh pengelolaan kelas, penguasaan materi belajar, strategi mengajar dan penggunaan media belajar. Profesional dalam Kamus Besar Bahasa Indonesia dari kata "profesi" yang artinya jabatan dibidang pekerjaaan yang memerlukan keahlian (keterampilan .kejuruan, dan sebagainya). Guru yang professional adalah guru yang memiliki kemampuan yang mumpuni dalam melaksanakan tugas jabatannya. Menurut Rebore (1991) guru yang professional memiliki karakteristik : 1) paham, menerima, dan melaksanakan tugas, 2) mampu melakukan kerja sama yang efektif baik dengan pimpinan, sesama guru, karyawan, peserta didik maupun masyarakat, 3) ada kemampuan untuk mengembangkan visi dan jabatannya secara terus menerus, 4) pelayanan tugas diutamakan, 5) mengarahkan, menekan, dan menumbuhkan pola perilaku peserta didik, serta melaksanakan kode etik jabatan.

Peraturan Menteri Pendidikan Nasional nomor 16 tahun 2007 tentang Standar Kualifikasi Akademik dan Kompetensi Guru disebutkan bahwa ada empat macam kompetensi yang harus dimiliki dan dikuasai oleh guru, yaitu : kompetensi pedagogik, kompetensi kepribadian, kompetensi sosial, dan kompetensi professional. Adapun kompetensi profesioan yang harus dimiliki oleg guru adalah: 1) mampu menguasai materi, struktur, konsep, dan pola pikir keilmuan sesuai dengan bidang studi yang diampuhnya, 2) menguasai kompetensi inti dan kompetensi dasar, 3) mengembangkan materi ajar secara kreatif, 4) mengembangkan keprofesionalan secara berkelanjutan dengan melakukan Tindakan reflektif, dan 5) memanfaatkan teknologi informasi dan komunikasi untuk berkomunikasi dan mengembangkan diri.

Siklus 3M (Mengkomunikasikan, Memantau, Mendeskripsikan) meningkatkan Keprofesionalan Guru dalam Pembelajaran Daring 
Siklus 3M dilaksanakan pertama kali pas diberlakukannya kebijakan untuk pembelajaran daring, yaitu pada hari Senin, tanggal 16 Maret 2020 sampai sekarang dan terus dilaksanakan untuk melakukan refleksi terus menerus sehingga terbentuk keprofesionalan guru yang berkualitas yang berimbas pada terwujudnya peserta didik yang berkarakter pancasila. Sebelum pelaksanaan Siklus 3M ada beberapa yang harus dipersiapkan, yaitu media yang harus digunakan (Android/Hp), jaringan internet, dan pembentukkan Group WhatsApp Kelas yang anggotanya saya sendiri sebagai kepala sekolah, wali kelas, guru mata pelajaran yang mengajar dikelas tersebut, guru BK, dan peserta didik., Group WhatsApp Wali Murid tiap Kelas, yang anggotanya wali kelas dan wali murid, Group WhattsApp Prestasi yang sebelumnya sudah ada anggotanya kepala sekolah dan semua guru, Google Classroom Prestasi.

Tahap-tahap Siklus 3M pada proses pembelajaran daring adalah :

1. Mengkomunikasikan

Ada beberapa macam bentuk komunikasi yang dilakukan pada proses pembelajaran daring, yaitu : komunikasi interpersonal, komunikasi kelompok baik kelompok kecil maupun kelompok besar, dan komunikasi organisasi. Komunikasi interpersonal dilakukan baik secara langsung (tatap muka) maupun tidak langsung (melalui media). Komunikasi ini dilakukan pada saat guru memberikan hasil kinerja individu, atau yang memerlukan bimbingan, teguran, dan ada tugas tambahan khusus yang dibebankan kepada guru sebagai bentuk umpan balik yang harus dilakukan oleh komunikator (kepala sekolah). Sedangkan komunikasi kelompok kecil dilakukan sesuai dengan kelompok mata pelajaran (MGMP), kepanitiaan yang jumlahnya terbatas, dan wakil kepala sekolah serta koordinator urusan. Komunikasi kelompok besar dilakukan pada saat work shop, pelatihan, rapat koordinator seluruh dewan guru, dan menganalisi hasil suatu kegiatan yang sedang dilaksanakan maupun yang sudah dilaksanakan.

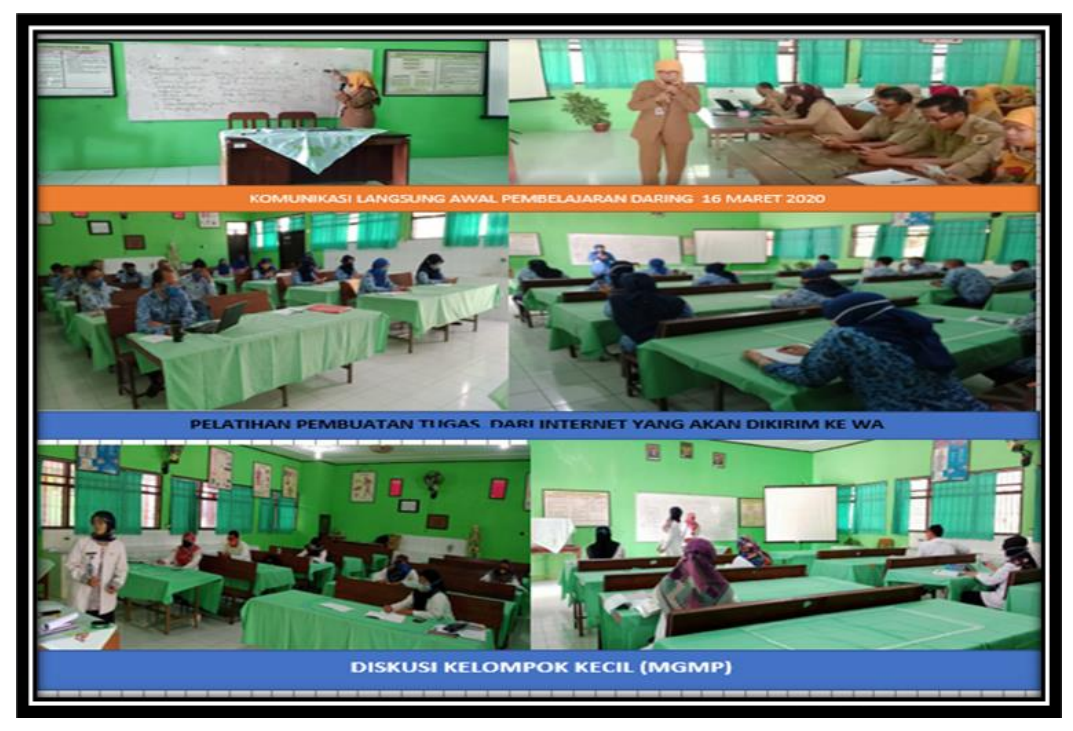

Gambar 6: Kegiatan Mengkomunikasikan

2. Memantau

Pemantaun dilaksanakan baik secara langsung maupun tidak langsung. Pemantauan yang utama adalah proses pembelajaran daring, yaitu dengan melihat di group WhatsApp Kelas. Dengan masuk menjadi anggota disemua kelas, saya selaku pemimpin bisa langsung melakukan supervise proses pembelajaran daring 28 kelas. Kegiatan memantau ini meliputi : a) ketepatan waktu dalam memberikan pembelajaran, b) bentuk materi ajar yang diberikan , c) motode pembelajaran yang 
digunakan , d) bentuk tugas yang diberikan kepada peserta didik, e) keaktipan berkomunikasi dengan peserta didik , f) jumlah peserta didik yang aktif mengikuti pembelajaran dan mengumpulkan tugas yang diberikan guru). Pemantauan juga dilakukan secara klasikal pada kegiatan yang dilakukan oleh sekolah, misalnya : Penilaian Harian Bersama, Penilaian Tengah Semester, dan Penilaian Akhir Semester dari mulai perencanaan, pelaksanaan, analisis hasil kegiatan, sampai pembuatan laporan kegiatan serta rencana tindak lanjut yang akan dilakukan

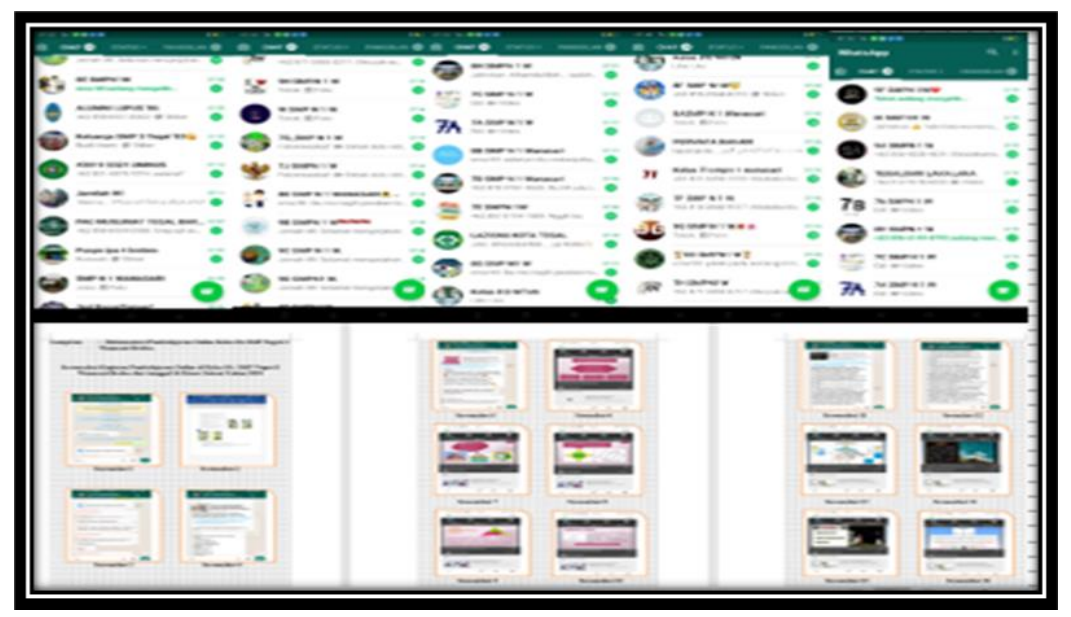

Gambar 7 : Kegiatan Memantau

3. Mendeskripsikan

Tahap mendeskripsikan dilakukan dari hasil produk komunikasi / hasil kinerja guru setelah dilakukan pemantauan. Tujuan inti dari mendeskripsikan adalah apakah kinerja guru sudah sesuai dengan standar operasional pekerjaannnya atau tidak. Apakah kesepakatan yang dihasilkan sesuai atau ada yang harus diubah, apakah kebijakan yang dilakukan tepat, bisa dilaksanakan, atau tidak. Apakah produk yang dihasilkan guru perlu ada perbaikan, dikembangkan, atau perlu pengubahan strategi atau metode karena tidak sesuai dengan kondisi dan situasi yang ada. Pada kegiatan ini yang diutamakan adalah data prestasi hasil belajar peserta didik imbas dari kinerja guru. Hasil akhir dari mendeskripsikan adalah dokumen yang sudah tidak mengalami perbaikan lagi yang selanjutnya untuk dicetak sebagai dokumen.

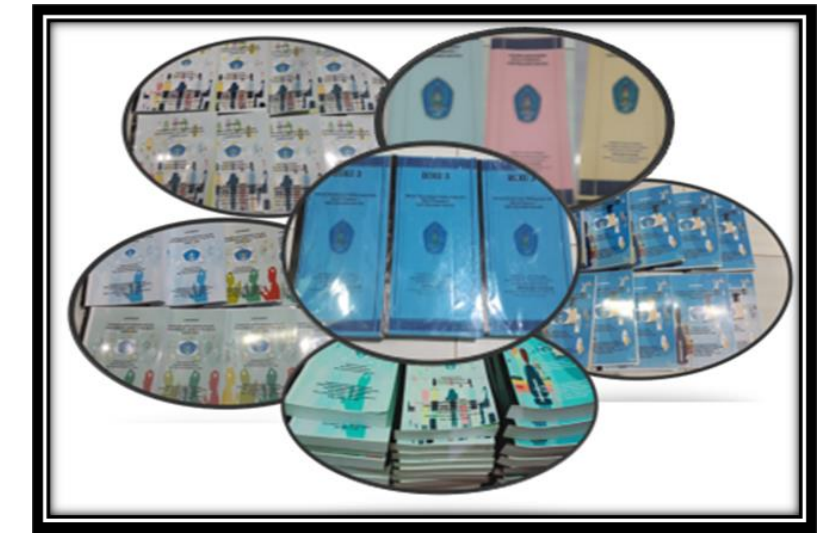

Gambar 8: Hasil Produk Kinerja Guru

Hasil Peningkatan Keprofesionalan Guru Melalui Siklus 3M (Mengkomunikasikan, Memantau, Mendeskripsikan) dalam Pembelajaran Daring 
Supervisi pada pembelajaran daring dengan menggunakan Siklus $3 \mathrm{M}$ ternyata berdampak pada peningkatan kompetensi profesional guru baik pada pengetahuan, keterampilan, maupun sikap. Hal ini dapat dilihat dari samakin tingginya sikap percaya guru dalam pembelajaran daring, peserta didik semakin mandiri, dan kreatif dalam mengikuti dan memberikan umpan balik tugas yang diberikan oleh guru. Adapun peningkatan keprofesionalan guru dapat diuraikan sebagai berikut:

A. Komunikasi

Komunikasi yang terus menerus baik secara langsung (tatap muka) maupun tidak langsung (menggunakan media) ternyata dapat:

1. Meningkatkan keterampilan mengupdate internet, khususnya yang terkait dengan materi pelajaran yang diampunya yang berdampak pada:
a. Peningkatan literasi
b. Peningkatan kemampuan dalam penguasaan materi pelajaran
c. Ketepatan dalam pemilihan bahan ajar
d. Peningkatan keterampilan dalam mendesain pembelajaran daring
e. Kreatif dan inovatif dalam menyajikan materi pelajaran

2. Meningkatkan keterampilan penggunaan dan pemanfaatan media komunikasi (Hp dan Laptop) sebagai media pembelajaran yang mampu berfungsi untuk:
a. Memudahkan proses setting pembelajaran
b. Meningkatnya kemampuan mengelola pembelajaran
c. Meningkatnya kemampuan dalam mengontrol proses pembelajaran

d. Penggunaan CBT baik pada Penilaian Harian (PH), Penilaian Tengah Semester (PTS) dan Penilaian Akhir Semester (PTS) sangat bermanfaat sekali dalam mewujudkan penilaian yang transparan, obyektif, dan efektif. Selain itu juga membiasakan guru membuat penilaian sendiri juga menghemat tenaga, waktu cepat, dan hemat biaya. Penilaian menggunakan CBT begitu soal dikerjakan selesai, saat itu juga nilai langsung keluar dan bisa digunakan juga untuk menganalisis setiap butir soal, mana soal yang perlu perbaikan atau penganyaan Penilaian dengan menggunakan CBT juga menghemat biaya karena tidak menggunakan kertas, ballpoin, atau guru yang mengawasinya.

e. Penggunaan Youtube juga sangat membantu guru menggantikan peranya, yang memudahkan peserta didik memahami materi dan melakukan umpan balik semakin komunikatif.

f. Mendukung gaya belajar yang modern mengikuti dunia global

g. Memotivasi peserta didik

h. Meningkatkan kerjasama

3. Komunikasi semakin efektif, yang berimbas pada: peningkatan percaya diri baik dari guru maupun peserta didik, menimbulkan saling pengertian, meningkatkan semangat untuk bekerja (bekerja tepat waktu, dan melaksanakan tugas bukan merupakan beban lagi tapi kewajiban yang menyenangkan)

4. Keinginan untuk menjadi lebih baik (bulan Oktober 2020 ada tiga guru yang naik pangkat, dan bulan Nopember ada lima guru yang mengajukan naik pangkat yang sebelumnya naik pangkat bukan suatu keharusan)

B. Memantau

Kegiatan memantau baik secara langsung maupun tidak langsung melalui media (Hp) lewat WhatsApp (Kelas dan Prestasi), Google Classroom, Gmail sangat membantu pada proses pembelajaran daring, hal ini karena :

1. Dapat mengetahui dengan cepat apakah proses pembelajaran daring berjalan sesuai dengan perencanaan ataukah tidak (misal: pembelajaran dimulai jam 07.30 ternyata sudah lebih dari jam 07.30 belum memberikan tugas daringnya)

2. Mempercepat mengadakan perubahan atau perbaikan seandainya pekerjaan belum sesuai dengan tujuan yang sudah ditentukan. 
3. Mendorong guru untuk melakukan komunikasi yang efektif pada saat pembelajaran (misalnya banyak peserta didik yang bertanya karena kurang paham pada tugas yang diberikan guru, guru harus segera melakukan komunikasi balik menjawab atau menjelaskan sampai peserta didik jelas).

4. Menimbulkan kepuasan dan memotivasi kinerja guru

C. Mendeskripsikan

Kegiatan mendesktipsikan utamanya adalah memberikan penilaian kinerja produk dari kinerja guru, juga mendorong guru untuk selalu melakukan refleksi terhadap kinerjanya dengan harapan selalu berubah untuk menjadi yang lebih baik lagi. Mendeskripsikan sangat bermanfaat diantaranya adalah:

1. Memberikan kepuasan pada guru karena merasa dihargai kinerjanya

2. Mendorong guru untuk melakukan kinerja yang lebih baik lagi.

3. Membiasakan tertib administrasi

\section{SIMPULAN}

Penggunaan Siklus 3M (mengkomunikasikan, Memantau, Mendeskripsikan) pada pembelajaran daring ternyata sangat efektif untuk meningkatkan keprofesionalan guru. Adapun peningkatan keprofesionalan guru sebagai berikut:

1. Peningkatan penguasaan materi, struktur, konsep, dan pola pikir keilmuan yang mendukung mata pelajaran yang diampuhnya.

2. Peningkatan pemahaman, penguasaan, dan mengembangkan kompetensi inti, kompetensi dasar, dan tujuan pembelajaran yang saling berkesinambungan sesuai dengan materi ajar, dan instrument penilaian.

3. Peningkatan kemampuan dalam mengembangkan materi pembelajaran secara kreatif

4. Peningkatan mengembangkan keprofesionalan secara berkelanjutan dengan melakukan tindakan reflektif (melakukan refleksi dan memanfaatkannya terhadap kinerjanya sendiri, mengikuti kemajuan jaman dengan belajar dari berbagai sumber)

5. Peningkatan keterampilan dalam memanfaatkan teknologi informasi dan komunikasi dalam berkomunikasi untuk pengembangan diri.

\section{DAFTAR PUSTAKA}

Alma Buchari (2014). Guru Profesional Maaenguasai Metode dan Terampil Mengajar. Bandung. CV Alfabeta

Badan Pengembangan dan Pembinaan Bahasa Kementerian Paendidikan dan Kebudayaan (2018). Kamus Besar Bahasa Indonesia. Jakarta .CV.Adi Perkasa. Edisi Kelima

Daryanto (2013). Standard Kompetensi dan Penilaian Kinerja Guru Profesional. Yogyakarta. Gava Media

Juni Priansa (2014). Kinerja dan Profesionalisme Guru. Bandung. CV.Alfabeta

Mulyana Deddy (2013). Ilmu Komunikasi Suatu Paengantar, Bandung. Remaja Rosdakarya.

Riyana Cepi, Konsep Pembelajaran Online, Modul-1

Salinan Lampiran Peraturan Menteri Pendidikan dan Kebudayaan nomor 22 tahun 2016 tentang Standar Proses Pendidikan Dasar dan Menengah

Surat Edaran Menteri Pendidikan dan Kebudayaan nomor 4 tahun 2020 tentangPelaksanaan Kebijakan Pendidikan dalam Masa Darurat Penyebaran Corona Virus Disease (Covid-19

Ika Handarini, (2020), Paembelajaran Daring Sebagai Upaya Study Froms Home (SFH) Selama Pandemi Covid-19. Jurnal Pendidikan Administrasi Perkantoran (JPAP), volume 8 nomor 3 (Online). Tersedia: https://journal.unesa.ac.id/index.php/jpap.

Wibawanto, Pemanfaatan GoogleForm sebagai Media Pembelajaran Jarak Jauh Atasi Penyebaran Covid-19 (Online). Kamis, 24 Desember 2020 
Makmur Yandi Komunikasi Umpan Balik (Online). Tersedia : https://slideplayer. info/slide/13063356/ . Jumat, 18 Desember 2020.

Nararya Sybilla (2017). Apa yang Dimaksud Dengan Umpan Balik (Feedback) dalam Komunikasi? (Online). Tersedia : https://www.dictio.id/t/apa-yang-dimaksuddengan-umpan-balik-feedback-dalam-komunikasi/9058 . Jumat, 18 Desember 2020

Questibriliain (2019) Mengenal Feedback: dari Komunikasi Massa sampai Dunia Bisnis (Online). Tersedia: https://www.jojonomic.com/blog/feedback/. Jumat, 18 Desember 2020

Tasropi, (2020). Penggunaan Google Form sebagai Alat Penilaian Pembelajaran. (online). Tersedia: https://radarsemarang.jawapos.com/rubrik/untukmuguruku/2020/10/12/penggunaan-google-form-sebagai-alat-penilaianpembelajaran/\#: :text=Adapun\%20fungsi\%20Google\%20Form\%20untuk,kepada \%20orang\%2Dorang\%20secara\%20online. Kamis, 24 Desember 2020.

Zulfahmi,(2017). Pengertian Sistem Pendidikan Terbuka (Online). Tersedia: https://ajoefahmi.blogspot.com/2017/06/pengertian-sistem-pendidianterbuka.html. (Rabu, 16 Desember 2020)

Widiawati Ana (2020) . Computer Based Test (CBT) - Pengertian, Kelebihan, Kekurangan dan Cara Membuatnya (Online) Tersedia: https:// penerbitbukudeepublish.com/computer-based-test/. Minggu, 20 Desember 2020.

Wikimedia, (2020). Pendidikan Terbuka (Online). Tersedia: https://id.wikipedia. org/wiki/Pendidikan_terbuka\#: :text=Pendidikan\%20terbuka\%20(bahasa\%20Ing gris\%3A\%20open,siswa\%20kendali\%20didalam\%20strategi\%20pembelajaran. (Rabu, 16 Desember 2020).

https://pengertiandefinisi.com/pengertian-sekolah-dan-fungsi-sekolah/ diakses tanggal 10 Agustus 2020

https://www.gurupendidikan.co.id/pengertian-strategi/ diakses tanggal 13 Agustus 2020

https://www.psikolif.com/pengertian-piring/ diakses tanggal 13 Agustus 2020

https://www.academia.edu/28949865/Pengertian_Gelas_Dan_Kaca diakses tanggal 13 Agustus 2020

https://foresteract.com/plastik/ diakses tanggal 13 Agustus 2020

https://pendidikan.co.id/pengertian-sekolah-fungsi-unsur-beserta-jenjangnya/ diakses tanggal 20 Agustus 2020 